\title{
UJI TOKSISITAS AKUT SENYAWA ETIL p-METOKSISINAMAT YANG DIISOLASI DARI RIMPANG KENCUR (Kaempferia galanga L)
}

\author{
Sara Nurmala \\ Program Studi Farmasi, FMIPA, Universitas Pakuan, Bogor \\ E-mail: sara.nurmala@gmail.com
}

\begin{abstract}
ABSTRAK
Pada rimpang tanaman kecur (Kaempferia galanga $L$.) terdapat senyawa etil pmetoksisinamat yang memiliki aktivitas-aktivitas farmakologis diantaranya sebagai analgesik dan antiinflamasi serta berpotensi sebagai tabir surya. Etil p-metoksisinamat dapat diisolasi dengan mudah dengan hasil rendemen yang relatif tinggi sehingga sangat berpotensi dijadikan sumber bahan obat alami. Tujuan dari penelitian ini adalah untuk menguji toksisitas akut senyawa etil p-metoksisinamat yang disolasi dari rimpang kencur. Serbuk rimpang kencur diekstrak menggunakan pelarut n-heksan sebanyak 4 kali. Etil pmetoksisinamat diidentifikasi dan diisolasi dari ekstrak dengan metode uji jarak lebur dan analisis KLT. Dari hasil uji didapatkan nilai jarak lebur p-metoksisinamat adalah 48$48,5^{\circ} \mathrm{C}$ dan dari hasil analisis KLT dengan fase gerak metanol : aseton (2:1) didapatkan bahwa etil p-metoksisinamat memiliki nilai Rf : 0,68. Hasil analisis spektrofotometri UVVIS senyawa etil p-metoksisinamat dalam pelarut metanol memberikan spektrum dengan serapan maksimum masing-masing pada 307,0 nm dan 226,0 nm. Uji toksisistas akut dilakukan dengan menghitung nilai kisara median lethal dose (LD50) senyawa etil pmetoksisinamat yang diberikan secara oral terhadap kelompok-kelompok tikus uji dengan variasi dosis 50, 100, 500, 1000 dan $2.000 \mathrm{mg} / \mathrm{Kg}$ BB. Hasil uji menunjukan bahwa nilai median LD50 dicapai pada pemberian dosis $3.652 \mathrm{mg} / \mathrm{Kg}$ BB. Dengan demikian dapat disimpulkan bahwa senyawa etil p-metoksisinamat termasuk senyawa obat baru dengan kategori toksik sedang.
\end{abstract}

Kata Kunci: Kencur, etil p-metoksisinamat, toksisitas akut, LD50

\section{ACUTE TOXICITY OF ETHYL $P$-METHOXYCINNAMATE COMPOUND ISOLATED FROM KAEMPFERIA GALANGA L}

\begin{abstract}
The main content found in the rhizome Kaempferia galanga L. is the ethyl $p$ methoxycinnamaten which has been proved to have many pharmacological activities such as an analgesic and anti-inflammatory, and has a potent as a sunscreen agent. The ethyl $p$ methoxycinnamate can be isolated easily and the yield a relatively large number of compound so that became the very potential source of a natural medicine. The extraction of Kaempferia galanga was using n-hexane solvent, followed by identification and isolation of ethyl $p$-methoxycinnamate using the melting range test and the TLC analysis methods. The melting value of ethyl $p$-methoxycinnamate was $48-48,5^{\circ} \mathrm{C}$ and the $\mathrm{Rf}$ value obtained from TLC analysis using mobile phase methanol:acetone $(2: 1)$ was 0.68 . The results of UV-VIS spectrophotometric analysis in methanol solvent shows that the maximum absorption value ethyl $p$-methoxycinnamate compound occur at $307.0 \mathrm{~nm}$ and $226.0 \mathrm{~nm}$ respectively. The acute toxicity was determined by calculating the median lethal dose (LD50) value of ethyl $p$-methoxycinnamate on a several groups of mice administered with different dose of ethyl $p$-methoxycinnamate $(50,100,500,1000$ and 2,000 mg / Kg). The value obtained median lethal dose (LD50) obtained was $3,652 \mathrm{mg} / \mathrm{Kg}$ animal weight.
\end{abstract}


It can be concluded that ethyl p-methoxycinnamate is the natural compound with moderate toxicity category.

Keywords: Kaempferia galanga L., acute toxicity, ethyl p-methoxycinnamate, LD50

\section{PENDAHULUAN}

Penelitian-penelitian terhadap kandungan dari rimpang kencur telah banyak dilakukan antara lain penelitianpenelitian terhadap senyawa etil pmetoksisinamat yang merupakan turunan dari sinamat (Darwis dkk., 1991). Senyawa ini yang diduga memiliki khasiat diduga memiliki khasiat sebagai analgesik dan antiinflamasi juga dapat bersifat sebagai agen tabir surya (Mulyadi T., 2009). dengan memodifikasi perpanjangan rantai karbon. Senyawa etil p-metoksisinamat adalah turunan sinamat yang berasal dari jalur biosintesis asam shikimat dan memiliki kerangka karbon C6 - C3, terdiri dari cincin benzen ( C6 ) yang terikat pada ujung rantai karbon ( $\mathrm{C} 3$ ) disebut dengan senyawa fenolik alam dari golongan fenilpropanoid (DepKes RI., 1995). Di alam turunan sinamat terdapat dalam bentuk ester atau glikosidanya. Etil p-metoksisinamat terdapat di alam dalam bentuk ester berwujud padatan kristal berwarna putih kekuningan dan mempunyai bau khas aromatis yang sangat kuat (Fahmi, 1991).<smiles>CCOC(=O)/C=C/c1ccc(OC)cc1</smiles>

(E)-ethyl 3-(4-methoxyphenyl)acrylate (Etil p-metoksisinamat)

Pada penelitian ini dilakukan uji toksisitas akut yang bertujuan untuk menentukan toksisitas suatu zat atau senyawa tertentu terhadap hewan uji. Uji toksisistas akut diperlukan untuk mengetahui derajat efek toksik sesuatu zat atau senyawa yang terjadi dalam waktu singkat setelah pemberian dalam dosis tunggal zat atau senyawa tersebut terhadap hewan uji. Batasan waktu singkat disini ialah rentang waktu selama 24 jam setelah pemberian senyawa.

Parameter yang digunakan untuk mengetahui toksisitas akut suatu zat atau senyawa adalah nilai median lethal dose atau LD50. Nilai LD50 didefinisikan sebagai dosis tunggal suatu zat atau senyawa yang secara statistik diharapkan akan membunuh 50\% hewan uji. Senyawa etil p-metoksisinamat pada penelitian ini diisolasi dari ekstrak nheksan rimpang kencur. Kemurniannya diuji menggunakan metode uji jarak lebur, kemudian diidentiikasi dan diisolasi mengunakan KLT dan Spekrofotometri Uv-Vis.

\section{METODE PENELITIAN \\ Pengumpulan Bahan}

Bahan yang digunakan dalam penelitian ini adalah rimpang kencur, yang diambil dari perkebunan daerah Leuwiliang, Kabupaten Bogor.

\section{Pembuatan Ekstrak n-heksan Kencur}

Sebanyak masing-masing $0,5 \mathrm{~kg}$ serbuk kering Kencur (Kaempferia galanga L.) murni diperkolasi dengan $1 \mathrm{~L}$ n-heksan dalam tabung perkolator selama 24 jam. Selama perendaman dilakukan pengocokan setiap 6 jam sekali selama 15 menit. Setelah 1 hari rendaman disaring, filtrat diambil dan masukan ke alat rotary evaporator sampai menghasikan ekstrak kental yang selanjutnya didinginkan sehingga menjadi serbuk kristal etil pmetoksisinamat dan digunakan untuk uji toksisitas akut.

Nilai rendemen ekstrak dihitung dengan membandingkan berat awal 
simplisia dan berat akhir ekstrak yang dihasilkan. Rendemen merupakan parameter standar mutu ekstrak serta penentuan efesiensi ekstraksi. Nilai persentase rendemen etil $\mathrm{p}$ metoksisinamat dihitung terhadap serbuk rimpang kencur kering dengan larutan nheksan adalah $1.19 \%$.

\section{Analisis Karakteristik Serbuk Kristal etil p-metoksisinamat \\ Kromatografi Lapis Tipis}

Untuk uji kromatografi lapis tipis, dibuat eluen/fase gerak metanol dan aseton dengan perbandingan 2:1 dan untuk fase diam digunakan Silika gel GF 254. Sebanyak $10 \mathrm{~mL}$ sampel $1 \%$ disiapkan dengan mengencerkan ekstrak menggunakan aquadem. Standar baku pembanding etil p-metoksisinamat $1 \%$ juga disiapkan dengan pengencer aquadem. Chamber untuk meletakkan kromatogram dijenuhkan dengan eluen yang akan digunakan. Larutan sampel dan larutan standar ditotolkan pada lempeng, dibiarkan kering kemudian di elusi pada chamber yang telah disiapkan. Lempeng KLT yang telah dielusi dideteksi menggunakan sinar UV 254. Nilai Rf kemudian dihitung dari jarak spor yang terbentuk berbanding jarak akhir. Hasil analisis KLT dengan fase gerak metanol:aseton (2:1) menunjukkan bahwa senyawa etil $\mathrm{p}$-metoksisinamat $\mathrm{m}$ nilai $\operatorname{Rf} 0,68$.

\section{Uji Jarak Lebur}

Sampel yang diperiksa harus kering dan digerus jadi serbuk, kemudian dimasukkan ke dalam pipa kapiler yang tertutup sebelah ujungnya, berdinding setebal 0,10 - 0,15 mm. Panjang kapiler secukupnya agar ujung yang terbuka berada di atas permuakaan cairan dalam alat tile dengan diameter sebelah dalam $0,9-1,1 \mathrm{~mm}$.

Lekatkan pipa kapiler tersebut pada termometer, dimana isinya diusahakan sedekat mungkin pada tengah-tengah pencadang raksa. Letakkan pencadang raksa di tengah tabung yang vertikal di tile. Panasi pipa samping tile dengan api kecil sampai kurang lebih $15^{\circ} \mathrm{C}$ dibawah titik lebur diduga, kemudian dipanasi pelan-pelan dan teratur dengan kecepatan kurang lebih $2^{\circ} \mathrm{C}$ per menit. Bagianbagian yang melekat pada dinding kapiler meleleh terlebih dahulu, temperatur dimana bahan di tengah pipa kapiler itu melebur semuanya dicatat sebagai temperatur titik leburnya. Hasil analisis titik lebur senyawa etil p-metoksisinamat adalah $48,5^{\circ} \mathrm{C}$.

\section{Spektrofotometri UV-VIS}

Pengujian kadar etil pmetoksisinamat dilakukan menggunakan alat spektrofotometer UV-VIS dengan pelarut metanol. Hasil analisis spektrofotometri senyawa standar etil pmetoksisinamat dalam pelarut metanol memberikan spektrum dengan serapan maksimum masing-masing pada 307,0 nm dan $226.0 \mathrm{~nm}$ (Masida, 2009).

\section{Pembuatan Sediaan Uji Toksisitas Akut}

Uji toksisitas akut mengacu pada pedoman dari The Organization for Economic Co-operation and Development (OECD) 425 yaitu Up and Down Procedure (Lu F.C., 1995). Sebelum pemberian senyawa uji, mencit dipuasakan satu malam tetapi tetap diberi minum. Senyawa uji disuspensikan dengan larutan Na-CMC 0,5\%.

\section{Limit Test}

Mencit telah dipuasakan ditimbang dan diberikan sediaan senyawa uji peroral pada dosis tunggal $2000 \mathrm{mg} / \mathrm{kg}$ BB. Volume Administrasi Obat (VAO) dihitung sesuai dengan bobot mencit, yaitu $60 \mathrm{mg} / 0,2 \mathrm{~mL}$. Setelah pemberiaan sediaan uji, pada 6 jam pertama dilakukan pengamatan selama 30 menit, dilanjutkan dengan pengamatan setiap 12 jam selama 48 jam. Tanda-tanda toksisitas yang diamati meliputi kondisi kulit dan bulu, mata, konvulsi, tremor, diare, dan 
kematian. Apabila setelah 48 jam mencit pertama masih hidup dan tidak menunjukkan tanda-tanda toksisitas ataupun kematian, maka pengujian dilanjutkan pada 4 mencit lainnya. Apabila terdapat 3 hewan coba yang mati, maka uji dilanjutkan dengan main test.

\section{Uji Toksisitas Akut Oral etil p- metoksisinamat}

Efek toksisitas akut oral etil pmetoksisinamat dievaluasi terhadap kelompok mencit dengan variasi pemberian dosis 50, 100, 500, 1000 dan $2.000 \mathrm{mg} / \mathrm{Kg}$ BB secara oral. Perilaku dan kondisi hewan coba diamati sampai 48 jam setelah perlakuan. Penghitungan LD50 dari sediaan uji dihitung dengan rumus:

$\log M=\log D+d(f+1)$

dimana :

M : Harga LD 50

$\mathrm{D}$ : Dosis terkecil yang digunakan

d : Log R (Log dari kelipatan dosis)

\section{HASIL DAN PEMBAHASAN}

Pada tahap uji didapat jumLah kematian $0,1,3,5$, 5 dengan dosis terkecil $50 \mathrm{mg} / 20 \mathrm{~g}$ BB. Berdasarkan rumus, maka didapat nilai $\mathrm{LD50}$ senyawa etil p-metoksisinamat adalah 3,6523 $(3,1715-4,2060) \mathrm{g} / \mathrm{kg}$ BB. Nilai yang didapatkan menunjukan bahwa senyawa etil p-metoksisinamat termasuk senyawa obat baru dengan kategori toksik sedang. Paramenter toksisitas baru terlihat berubah pada mencit yang diberi perlakuan dosis 1000 dan $2000 \mathrm{mg} / \mathrm{Kg}$ $\mathrm{BB}$ yaitu mencit mengalami tanda diare dan tremor.

\section{SIMPULAN}

1. Senyawa etil p-metoksisinamat dapat diisolasi dari rimpang kencur dengan pelarut n-heksan dengan rendemen $68 \%$ dihitung terhadap rimpang kencur.

2. Senyawa etil p-metoksisinamat dapat identifikasi menggunakan KLT, spektrofotometri UV-Vis dan jarak lebur.

3. Penetapan nilai LD50 senyawa etil pmetoksisinamat adalah 3,6523 (3,1715-4,2060) g/Kg BB, senyawa merupakan senyawa dengan kategori toksik sedang.

\section{SARAN}

Perlu dilakukan penelitian lebih lanjut tentang efek analgesik/efek antiinflamasi dari senyawa etil pmetoksisinamat secara in-vivo.

\section{DAFTAR PUSTAKA}

Darwis, S.N, A.B.D Modjo, dan Hasiyah S. 1991. Tumbuhan obat familia zingiberaceae. Bogor: Pusat Penelitian dan Pengembangan Tanaman Industri

DepKes RI. 1995. Farmakope Indonesia. Edisi IV. Direktorat Jenderal Pengawasan Obat dan Makanan. Jakarta.

Fahmi R. 1991. Isolasi dan Karakteristik struktur konstituen kimia utama kencur (Kaempferia galanga Linn) Skripsi. Padang: Pusat Pendidikan Universitas Negeri Padang. Padang.

Lu, F.C. 1995. Toksikologi Dasar Asas, Organ Sasaran, dan Penelitian

Resiko. Ed 2. Diterjemahkan oleh Edi Nugroho. UI Press. Jakarta.

Masida M. 2009. Penetapan kadar etil pmetoksisinamat dari tiga varietas rimpang kencur (Kaempferia galanga L) secara KLTDensitometri. Skripsi. Fakultas Farmasi Universitas Pancasila. Jakarta.

Mulyadi T. 2009. Senyawa tabir surya yang efektif dengan bahan baku senyawa aktif dari rimpang kencur (Kaempferia Galanga L.). 